\title{
1 Characterization of SARS-CoV-2 Genetic Material in Wastewater
}

3 Carolyn A Robinson ${ }^{\mathrm{a}, \mathrm{b}}$, Hsin-Yeh Hsieh ${ }^{c}$, Shu-Yu Hsu ${ }^{\mathrm{c}, \mathrm{d}}$, Yang Wang ${ }^{\mathrm{a}, \mathrm{b}}$, Braxton T Salcedo ${ }^{\mathrm{a}, \mathrm{b}}$, Jessica

4 Klutts $^{\mathrm{e}}$, Sally Zemmer ${ }^{\mathrm{e}}$, Anthony Belenchia ${ }^{f}$, Melissa Reynolds $^{f}$, Elizabeth Semkiw ${ }^{f}$, Trevor Foley ${ }^{\mathrm{g}}$,

5 XiuFeng Wan ${ }^{a, h, b}$, Chris G. Wieberg ${ }^{e}$, Jeff Wenzel ${ }^{f}$, Chung-Ho Lin ${ }^{c, d}$, Marc C Johnson ${ }^{a, b *}$

\section{AFFILIATIONS}

7 a. Department of Molecular Microbiology and Immunology, University of Missouri, School of Medicine, Columbia, MO, USA.

9 b. Christopher Bond Life Sciences Center, University of Missouri, Columbia, MO, USA.

10 c. School of Natural Resources, University of Missouri, Columbia, MO, USA.

11 d. Center of Agroforestry, University of Missouri, Columbia, MO, USA.

12 e. Water Protection Program, Missouri Department of Natural Resources, Jefferson City, MO.

13 f. Bureau of Environmental Epidemiology, Division of Community and Public Health, Missouri

14 Department of Health and Senior Services, Jefferson City, MO.

15 g. Missouri Department of Corrections, Jefferson City, MO.

16 h. Department of Electrical Engineering \& Computer Science, College of Engineering, University of

17 Missouri, Columbia, MO, USA.

$18 *$ Corresponding Author. 
medRxiv preprint doi: https://doi.org/10.1101/2021.07.19.21260777; this version posted July 25, 2021. The copyright holder for this preprint (which was not certified by peer review) is the author/funder, who has granted medRxiv a license to display the preprint in perpetuity.

It is made available under a CC-BY-NC-ND 4.0 International license .

SARS-CoV-2 genetic material has been detected in raw wastewater around the world

24 throughout the COVID-19 pandemic and has served as a useful tool for monitoring community

25 levels of SARS-CoV-2 infections. SARS-CoV-2 genetic material is highly detectable in a patient's

26 feces and the household wastewater for several days before and after a positive COVID-19 qPCR

27 test from throat or sputum samples. Here, we characterize genetic material collected from raw

28 wastewater samples and determine recovery efficiency during a concentration process. We find

29 that pasteurization of raw wastewater samples did not reduce SARS-CoV-2 signal if RNA is

30 extracted immediately after pasteurization. On the contrary, we find that signal decreased by

31 approximately half when RNA was extracted $24-36$ hours post-pasteurization and $~ 90 \%$ when

32 freeze-thawed prior to concentration. As a matrix control, we use an engineered enveloped RNA

33 virus. Surprisingly, after concentration, the recovery of SARS-CoV-2 signal is consistently higher

34 than the recovery of the control virus leading us to question the nature of the SARS-CoV-2 genetic

35 material detected in wastewater. We see no significant difference in signal after different 24-

36 hour temperature changes; however, treatment with detergent decreases signal 100 -fold.

37 Furthermore, the density of the samples is comparable to enveloped retrovirus particles, yet,

38 interestingly, when raw wastewater samples were used to inoculate cells, no cytopathic effects

39 were seen indicating that wastewater samples do not contain infectious SARS-CoV-2. Together,

40 this suggests that wastewater contains fully intact enveloped particles.

\section{KEYWORDS}

42 Coronavirus, COVID-19, Wastewater, Sewage, Surveillance, Pasteurization 
medRxiv preprint doi: https://doi.org/10.1101/2021.07.19.21260777; this version posted July 25, 2021. The copyright holder for this preprint (which was not certified by peer review) is the author/funder, who has granted medRxiv a license to display the preprint in perpetuity.

It is made available under a CC-BY-NC-ND 4.0 International license .

Severe acute respiratory syndrome coronavirus 2 (SARS-CoV-2), the causative agent of coronavirus disease 2019 (COVID-19), was first identified in Wuhan, China in December 2019 and was declared a global pandemic by the World Health Organization (WHO) in March 2020. To date,

48 SARS-CoV-2 has produced > 175 million cases and > 3.8 million COVID-19 related deaths

49 worldwide (WHO, June $\left.16^{\text {th }}, 2021\right)$. SARS-CoV-2 has been shown to be spread primarily by 50 respiratory droplets and occasionally by aerosols [1].

51 SARS-CoV-2 has $75-80 \%$ nucleotide similarity to severe acute respiratory syndrome

52 coronavirus (SARS-CoV) that was responsible for outbreaks of severe acute respiratory syndrome

53 in 2002 and 2003 in Guangdong Province, China[2-5]. Both SARS-CoV and SARS-CoV-2 use the

54 cellular receptor Angiotensin-converting enzyme 2 (ACE2) which is highly expressed in the lung

55 and oral mucosa and expressed at lower levels in the digestive tract [6-8]. Due partially to

56 population sizes, material shortages, inaccessibility to laboratory equipment, a vast array of

57 disease severity, and healthcare coverage concerns, it has not been possible to test every

58 individual regularly for a SARS-CoV-2 infection. These disparities cause difficulty in monitoring

59 community spread.

60

It has been reported that SARS-CoV, SARS-CoV-2, and other coronavirus RNA is detectable

61 in feces of infected patients up to 6 to 10 days before symptom onset [9-14]. Additionally,

62 screening of sewage for the prevalence of viruses including SARS-CoV-2, SARS-CoV, Poliovirus,

63 noroviruses, adenoviruses, and rotaviruses, have been shown to correlate closely with the

64 occurrence of cases in the community [15-20]. This supports wastewater surveillance as a useful

65 method for monitoring community levels of SARS-CoV-2 infections. 
medRxiv preprint doi: https://doi.org/10.1101/2021.07.19.21260777; this version posted July 25, 2021. The copyright holder for this preprint (which was not certified by peer review) is the author/funder, who has granted medRxiv a license to display the preprint in perpetuity.

It is made available under a CC-BY-NC-ND 4.0 International license .

Unlike from sputum, samples collected from feces of infected patients do not generally

67 appear to contain infectious viral particles despite high levels of detectable viral RNA [21-23];

68 however, infectious particles cultured from feces has been reported before [24]. To date and to

69 the best of our knowledge, there have been no confirmed cases of COVID-19 linked directly to

70 wastewater treatment plants. Several groups have examined the survival rate of various other

71 coronaviruses in raw, unpasteurized wastewater, and generally conclude that after a maximum

72 of 3 days there is a $99.9 \%$ decrease in infectivity [25-27].

During periods of lower community infection rates, it was necessary to concentrate raw

74 wastewater samples to reliably detect SARS-CoV-2 genetic material by quantitative reverse

75 transcription polymerase chain reaction PCR (qPCR). Viral concentration from wastewater has

76 been done using several different methods, and comparison of methods has been the focus of

77 several manuscripts since early 2020 [28-30]. Our lab used a well-known Polyethylene glycol

78 (PEG) and $\mathrm{NaCl}$ method for viral concentration that has been used for over 50 years [31-33]. As a

79 control for viral recovery throughout concentration, we used a unique enveloped RNA virus.

80 Interestingly, we noticed a disparity in recovery rates between our control virus and SARS-CoV-2

81 signal, leading us to question the nature of genetic material detectable in wastewater. In this

82 manuscript, we examine recovery, temperature resistance, density, detergent resistance, and

83 infectivity and conclude that the genomic material detected in wastewater is enveloped and non-

84 infectious.

85

862 METHODS

$87 \quad 2.1$ Plasmids 
medRxiv preprint doi: https://doi.org/10.1101/2021.07.19.21260777; this version posted July 25, 2021. The copyright holder for this preprint (which was not certified by peer review) is the author/funder, who has granted medRxiv a license to display the preprint in perpetuity.

It is made available under a CC-BY-NC-ND 4.0 International license .

The NL4-3 derived HIV containing the CMV driven Puromycin resistance gene and lacking the accessory genes Vif, Vpr, Nef, and Env was using InFusion Cloning (TaKara). To make this construct, we used a previously described NL4-3 derived HIV-CMV-GFP provided by Vineet Kewal

91 Rammani (National Cancer Institute (NCl) - Frederick) [34]. This proviral vector lacks the

92 accessory genes vif, vpr, nef, and env and contains a CMV promoter driven GFP in the place of

93 nef. The NL4-3 derived HIV-CMV-GFP was digested using Stu1 and Xma1 (New England Biolabs

94 (NEB)) to remove the GFP gene, and a gBlock fragment (Integrated DNA Technologies (IDT)) of a

95 uniquely codon optimized Puromycin resistance gene was put in its place. The unique puromycin

96 resistance gene sequence is as follows:

ATGACAGAGTATAAGCCAACCGTCCGGCTCGCAACGAGAGACGATGTCCCGAGGGCAGTGCGCACGCTCGCC GCGGCCTTTGCGGACTACCCTGCAACAAGACACACTGTGGATCCCGATCGCCACATAGAGCGCGTGACTGAG CTGCAAGAACTGTTCCTTACCAGGGTGGGTCTCGATATCGGTAAGGTTTGGGTCGCCGACGACGGAGCGGCA GTGGCAGTCTGGACCACTCCTGAGAGCGTAGAAGCAGGCGCAGTGTTTGCAGAAATTGGCCCTAGAATGGCC GAATTGTCCGGTAGCCGGCTCGCTGCTCAGCAGCAGATGGAAGGCCTGCTCGCACCTCACAGACCCAAAGAA CCCGCGTGGTTCCTGGCGACAGTGGGAGTCAGTCCAGACCATCAGGGCAAAGGTCTCGGCTCAGCAGTTGTA CTGCCTGGGGTAGAGGCCGCAGAAAGGGCAGGGGTGCCGGCCTTCCTGGAAACATCTGCACCCAGAAACTT GCCTTTCTACGAGAGGCTGGGATTCACCGTTACCGCCGACGTGGAGGTGCCCGAAGGACCGCGCACTTGGTG CATGACGAGAAAGCCCGGGGCTTGA

107 was digested with EcoR1. A Wuhan strain N template was PCR amplified and infused using an 108 InFusion kit (Takara). 
medRxiv preprint doi: https://doi.org/10.1101/2021.07.19.21260777; this version posted July 25, 2021. The copyright holder for this preprint (which was not certified by peer review) is the author/funder, who has granted medRxiv a license to display the preprint in perpetuity.

It is made available under a CC-BY-NC-ND 4.0 International license .

The TaqMan probe (VIC-5' CGGTAAGGTTTGGGTCGCCGAC 3'-QSY) and the primer pair

112 (puro Forward: 5' CCCGATCGCCACATAGAGC 3'; puro Reverse: 5' CCATTCTAGGGCCAATTTCTGC

$\left.1133^{\prime}\right)$ were designed and used to target the puro RNA described above. Primers and probe specificity

114 was tested by BLAST analysis (NCBI) to prevent known nonspecific binding targets that could be

115 obtained in a human specimen. The choice of VIC fluorescent dye for the puro TaqMan probe is

116 for the application in the multiplex reactions with the SARS-CoV-2 $\mathrm{N}$ gene TaqMan probe utilizing

117 the FAM reporter.

A plasmid (described above) carrying a unique puro resistance gene fragment along with

119 a N gene fragment was constructed, purified from Escherichia coli, and used as standards for the

120 RT-qPCR assay to ensure an equal molar ratio of puro and $\mathrm{N}$ gene detection. A standard curve

121 was constructed at concentrations of 200,000 through 2 gene copies $\mu L^{-1}$ and utilized to

122 determine the copy number of the target puro gene in the spiked wastewater samples.

124 (Thermo Fisher cat\# A15299), $500 \mathrm{nM}$ of each primer, $125 \mathrm{nM}$ of each TaqMan probe, $5 \mu$ l of

125 wastewater RNA extract and RNase/DNase-free water to reach a final volume of $20 \mu \mathrm{L}$. All RT-

126 qPCR assays were performed in duplicate using a 7500 Fast real-time qPCR machine (Applied

127 Biosystems). The reactions were initiated with 1 cycle of Uracil N-glycosylase (UNG) incubation

128 at $25^{\circ} \mathrm{C}$ for 2 min to eliminate carryover and then 1 cycle of reverse transcription at $50^{\circ} \mathrm{C}$ for 15

$129 \mathrm{~min}$, followed by 1 cycle of activation of DNA polymerase at $95^{\circ} \mathrm{C}$ for $2 \mathrm{~min}$ and then 45 cycles of

$13095^{\circ} \mathrm{C}$ for $3 \mathrm{sec}$ for DNA denaturation and $55^{\circ} \mathrm{C}$ for $30 \mathrm{sec}$ for anneal and extension. The data is

131 collected at the $55^{\circ} \mathrm{C}$ extension step. 
medRxiv preprint doi: https://doi.org/10.1101/2021.07.19.21260777; this version posted July 25, 2021. The copyright holder for this preprint (which was not certified by peer review) is the author/funder, who has granted medRxiv a license to display the preprint in perpetuity.

\subsection{Concentration and Recovery}

Duplicate samples containing $50 \mathrm{~mL}$ of raw wastewater were collected and stored at $4^{\circ} \mathrm{C}$.

135

136

137

138

139

140

141

142

143 Viral RNA mini kit (cat\# 52906) in a QIAcube Connect (Qiagen cat\# 9002864). Additionally, $140 \mu \mathrm{L}$

144 of wastewater was collected prior to filtering the sample, after filtration (before addition of PEG

145

146 above.

147

148

149

150

151

152 153 Connect (Qiagen cat\# 9002864). Viral recovery was determined by qPCR as described above. 154 Statistics are a paired student's t-test run on Microsoft Excel.

\subsection{Stability Assessment}

Samples containing $50 \mathrm{~mL}$ of raw wastewater were collected and stored at $4^{\circ} \mathrm{C}$. Samples were mixed gently and split into $3 \times 16.7 \mathrm{~mL}$ aliquots. Aliquots were stored at either $4^{\circ} \mathrm{C}$, Room Temperature (RT) $\left(\sim 22^{\circ} \mathrm{C}\right)$, or $37^{\circ} \mathrm{C}$ for 24 hours. After 24 hours, $140 \mu \mathrm{L}$ of sample was collected, and RNA was extracted using the Qiagen QIAmp Viral RNA mini kit (cat\# 52906) in a QIAcube 
medRxiv preprint doi: https://doi.org/10.1101/2021.07.19.21260777; this version posted July 25, 2021. The copyright holder for this preprint (which was not certified by peer review) is the author/funder, who has granted medRxiv a license to display the preprint in perpetuity. It is made available under a CC-BY-NC-ND 4.0 International license .

\subsection{Pasteurization}

Duplicate samples containing $50 \mathrm{~mL}$ of raw wastewater were collected and stored at $4{ }^{\circ} \mathrm{C}$.

158 One $50 \mathrm{~mL}$ tube of each duplicate sample was kept at $4^{\circ} \mathrm{C}$, and the other $50 \mathrm{~mL}$ tube of sample was incubated at $60^{\circ} \mathrm{C}$ for 2 hours then concentrated as described above. RNA was extracted

160 from both pellets using the Qiagen QIAmp Viral RNA mini kit (cat\# 52906) in a QIAcube Connect

161 (Qiagen cat\# 9002864). Viral recovery was determined by qPCR as described above.

For pasteurization effect on signal 24 hours later, duplicate samples were pasteurized and

163 RNA extraction was done either immediately after the 2-hour incubation at $60^{\circ} \mathrm{C}$ or $24-36$ hours

164 after pasteurization. RNA was extracted from the samples using the Qiagen QIAmp Viral RNA mini

165 kit (cat\# 52906) in a QIAcube Connect (Qiagen cat\# 9002864). Viral recovery was determined by qPCR as described above. Statistics are a paired student's t-test run on Microsoft Excel.

\subsection{Freeze-Thaw Sensitivity}

Duplicate samples containing $50 \mathrm{~mL}$ of raw wastewater less than 1 week old were

170 collected and stored at $4{ }^{\circ} \mathrm{C}$. One $50 \mathrm{~mL}$ tube of each duplicate sample was kept at $4^{\circ} \mathrm{C}$, and the

171 other $50 \mathrm{~mL}$ tube of sample was stored at $-80^{\circ} \mathrm{C}$. for 36 hours then thawed and concentrated as

172 described above. RNA was extracted from both pellets using the Qiagen QIAmp Viral RNA mini

173 kit (cat\# 52906) in a QIAcube Connect (Qiagen cat\# 9002864). Viral recovery was determined by

174 qPCR as described above. Statistics are a paired student's t-test run on Microsoft Excel.

175

176

\subsection{Detergent Sensitivity}


medRxiv preprint doi: https://doi.org/10.1101/2021.07.19.21260777; this version posted July 25, 2021. The copyright holder for this preprint (which was not certified by peer review) is the author/funder, who has granted medRxiv a license to display the preprint in perpetuity.

It is made available under a CC-BY-NC-ND 4.0 International license .

Duplicate samples containing $50 \mathrm{~mL}$ of raw wastewater were collected and stored at $4{ }^{\circ} \mathrm{C}$.

178 One of each duplicate sample was treated with either $1 \%$ Triton X 100 or PBS for 2 hours at $37^{\circ} \mathrm{C}$.

179 RNA was extracted using the Qiagen QIAmp Viral RNA mini kit (cat\# 52906) in a QIAcube Connect

180 (Qiagen cat\# 9002864). Viral recovery was determined by qPCR as described above. Statistics are

181 a paired student's t-test run on Microsoft Excel.

182

183

\subsection{Density}

Samples containing $50 \mathrm{~mL}$ of raw wastewater were collected and stored at $4^{\circ} \mathrm{C} . \mathrm{NL} 4-3$

derived HIV containing CMV driven Puromycin resistance and lacking the accessory genes Vif,

$186 \mathrm{Vpr}$, Nef, and Env were added to raw samples at a concentration of $4.8 \times 10^{7}$ viral particles per

187 sample. Samples were concentrated as described above. Concentrated samples were then added

188 to a density gradient ranging from $0 \%$ to $28 \%$ iodixanol in a $0.25 \mathrm{M}$ sucrose dilutant according to

189 the Optiprep protocol (Sigma cat\# 92339-11-2). Gradients were spun in a Sorvall Discovery 100SE

190 ultracentrifuge at 31,000 RPM for 3 hours at $4^{\circ} \mathrm{C}$. After centrifugation, the gradient was

191 fractioned. RNA was extracted from each fraction using the Qiagen QIAmp Viral RNA mini kit

192 (cat\# 52906) in a QIAcube Connect (Qiagen cat\# 9002864). Viral recovery was determined by

193 qPCR as described above.

2.9 Infectivity

Fresh samples were filtered through a $0.22 \mu \mathrm{m}$ filter (Millipore cat\# SCGPOO525). For the

197 first recovery, $200 \mu$ l of each sample was inoculated to Vero E6 cells (CRL1586 ${ }^{\mathrm{TM}}$, ATCC) in 6-well

198 plates at a confluence of $\sim 90 \%$. After one hour of adsorption, the inoculum was removed, and 
medRxiv preprint doi: https://doi.org/10.1101/2021.07.19.21260777; this version posted July 25, 2021. The copyright holder for this preprint (which was not certified by peer review) is the author/funder, who has granted medRxiv a license to display the preprint in perpetuity.

It is made available under a CC-BY-NC-ND 4.0 International license .

199 the cells were washed with PBS and covered with fresh optiMEM (Gibco, Thermo Fisher

200 Scientific). Three days post inoculation, $1 \mathrm{~mL}$ of the supernatant from the last virus recovery was

201 centrifuged and inoculated to fresh Vero E6 cells for the second and third virus recovery and

202 cytopathic effect was observed. The SARS-CoV-2/human/USA/20x1003/2020 (GenBank

203 Accession ID: MW521470.1) virus was used as the positive control at a multiplicity of infection

204 (MOI) of 0.001.

205

206

\section{RESULTS}

207

\subsection{SARS-CoV-2 Signal Recovery Through Concentration.}

Generally, it has been necessary to concentrate wastewater samples for reliable

211 spread of COVID-19, we were able to reliably detect

212 signal in raw, unconcentrated wastewater. This allowed

213 us to compare signal before concentration and after

214 each subsequent step (Figure 1). We extracted RNA from

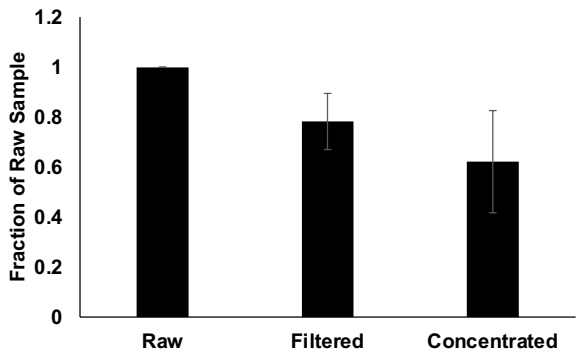

215 samples before filtration, after filtration, and after

216 concentration for qPCR quantification. Unconcentrated

217 sample numbers were multiplied based on the volume of

Figure 1. Recovery. $\mathrm{N}=9$. Raw samples were spun at $2,000 \times \mathrm{xg}$ for 5 minutes to remove large particulates, then vacuum filtered through a $0.22 \mu \mathrm{m}$ filter, and mixed with Polyethylene glycol (PEG) and $\mathrm{NaCl}$ solution for a final concentration of $12 \%$ PEG and $0.3 \mathrm{M} \mathrm{NaCl}$. Samples were mixed thoroughly and kept at $4^{\circ} \mathrm{C}$ for 1 hour, then spun at $12,000 \times g$ at $4^{\circ} \mathrm{C}$ for 2 hours. RNA was for 1 hour, then spun at $12,000 x g$ at $4{ }^{\circ} \mathrm{C}$ for 2 hours. RNA was extracted from pellet, and viral recovery was determined by qPCR. Wastewater was collected prior to filteing the sample, after filtration (before addition of PEG solution), and after concentration of virus. Signal from unconcentrated samples was multiplied based on the total volume of sample to be concentrated to allow for equal comparison at each step. Error

218 original sample to ensure that recovery could be

219 compared throughout the concentration process. Filtering preserved an average of $68 \%$ of signal and concentration preserved an average of $62 \%$ signal when compared to raw samples. 
medRxiv preprint doi: https://doi.org/10.1101/2021.07.19.21260777; this version posted July 25, 2021. The copyright holder for this preprint (which was not certified by peer review) is the author/funder, who has granted medRxiv a license to display the preprint in perpetuity.

It is made available under a CC-BY-NC-ND 4.0 International license .

\subsection{Pasteurization and Freeze-Thaw Can Reduce SARS-CoV-2 Signal.}

224 these pathogens, but some have suggested pasteurizing samples at $60^{\circ} \mathrm{C}$ for 1 to 2 hours to

225 inactivate potential pathogens [35]. To test the effect on signal due to pasteurization, duplicate

226 samples were kept at either $4^{\circ} \mathrm{C}$ or $60^{\circ} \mathrm{C}$ for 2 hours prior to RNA extraction (Figure $2 \mathrm{~A}$ ). We found

227 no significant difference between pasteurized and non-pasteurized samples ( $P$ value $=0.23)$ when

228 RNA was extracted

229 immediately after

230 pasteurization;

231 however, it is

A.

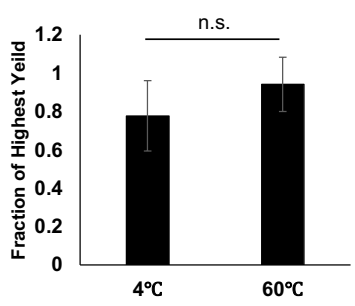

B.

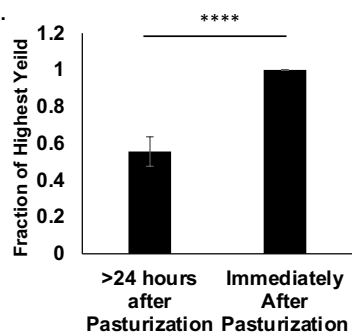

c.

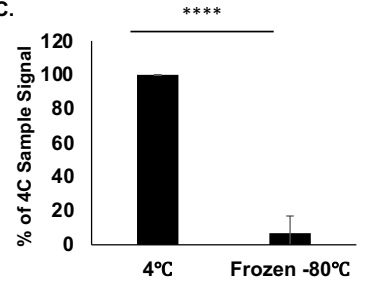

232 important to note that

Figure 2: Impact of Pasteurization and Freeze-Thaw. A) N=6. Duplicate samples were kept at $4^{\circ} \mathrm{C}$ or incubated at $60^{\circ} \mathrm{C}$ for 2 hours. Raw samples were concentrated, and RNA was extracted from the pellet. Viral recovery was determined by GPCR. Fraction of Highest yield was calculated by the ratio signal between treatments. Error bars represent standard deviation. PValue $=0.23 \mathrm{~B}$ ) $\mathrm{N}=6$. Duplicate samples were kept at $4^{\circ} \mathrm{C}$ or incubated at $60^{\circ} \mathrm{C}$ for 2 hours. RNA was extracted from raw samples either immediately after 2-hour incubation at $60^{\circ} \mathrm{C}$ or $24-36$ hours after pasteurization. Viral recovery was determined by qPCR.

233 signal dropped Fraction of Highest yield was calculated by the ratio signal between treatments. Error bars represent standard deviation. PValue $=2.05 \mathrm{E}-6$. C) $\mathrm{N}=6$. Duplicate raw samples were kept at kept at $4{ }^{\circ} \mathrm{C}$ or $-80{ }^{\circ} \mathrm{C}$ for 48 hours. Raw Samples were concentrated, and RNA was extracted from the pellet. Viral recovery was determined by qPCR. Error bars represent standard deviation. P-Value= 3.13E-6.

237 reduction in signal $\left(\mathrm{P}\right.$ value $\left.=2.05 \times 10^{-6}\right)$. This finding is important as protocols using pasteurization as a method to inactivate pathogens in wastewater prior to RNA extraction and

241 finding further stresses that processing of samples is time-sensitive, and storage of samples in a 
medRxiv preprint doi: https://doi.org/10.1101/2021.07.19.21260777; this version posted July 25, 2021. The copyright holder for this preprint (which was not certified by peer review) is the author/funder, who has granted medRxiv a license to display the preprint in perpetuity.

It is made available under a CC-BY-NC-ND 4.0 International license .

\subsection{SARS-CoV-2 Signal is Higher than Enveloped Virus Control.}

244

245

246

247

248

249 Vpr, Nef, and Env (Henceforth

250 called 'Puro Virus') was added to

251 raw wastewater samples at a
A.
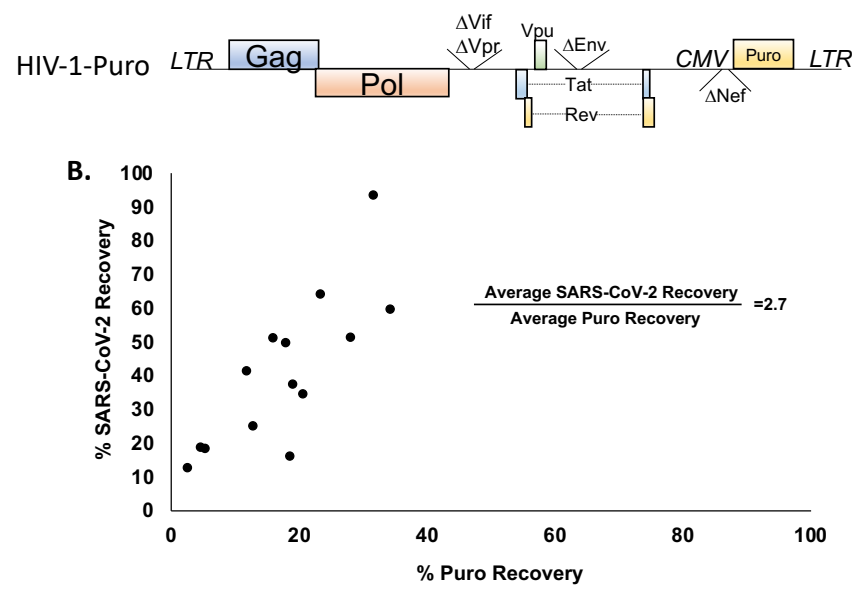

Figure 3: A) Schematic of Puro Virus Control. NL4-3 derived HIV containing CMV driven, uniquely codon optimized, Puromycin resistance and lacking the accessory genes Vif, Vpr, Nef, and Env. B) Relative Recovery of Puro Virus Signal and SARS-CoV-2 Signal. Samples were spiked with Puro Virus at a concentration of $4.8 \times 10^{7}$ viral particles per sample. RNA was extracted from samples both before and after concentration, and viral recovery was determined by qPCR.

252 concentration of $4.8 \times 10^{7}$ viral particles per sample (Figure $3 \mathrm{~A}$ ). Importantly, the Puro Virus

253 contains a uniquely codon optimized puromycin resistance gene. The unique sequence present

254 in the Puro Virus ensures that any signal detected throughout our experiments with this probe is

255 from our internal matrix control. Both SARS-CoV-2 and the Puro Virus are positive-sense RNA

256 contained in an envelope. Interestingly, upon comparison of signal detected in highly potent

257 samples before and after concentration, SARS-CoV-2 recovery was consistently higher than the

258 Puro Virus recovery (Figure 3B). On average, SARS-CoV-2 recovery was 2.7-fold higher than Puro

259 Virus recovery. The consistent disparity between the SARS-CoV-2 recovery and the Puro Virus

recovery was surprising and led us to hypothesize that the SARS-CoV-2 signal was coming from a

261 different source than enveloped RNA, such as non-enveloped ribonuclear complexes, as we

262 would expect that most enveloped particles would interact similarly with PEG during

263 concentration. Following this finding, we aimed to characterize the SARS-CoV-2 genetic material

264 detected in wastewater. 
medRxiv preprint doi: https://doi.org/10.1101/2021.07.19.21260777; this version posted July 25, 2021. The copyright holder for this preprint (which was not certified by peer review) is the author/funder, who has granted medRxiv a license to display the preprint in perpetuity.

\subsection{SARS-CoV-2 Signal Stability.}

After collection from a sewer shed, samples are

268 stored at $4^{\circ} \mathrm{C}$ until they are processed; however, we

269 wanted to test the stability of samples at a variety of

270 temperatures to determine if temperature control made

271 a large impact on SARS-CoV-2 signal. A portion of each

272 sample was kept at either $4^{\circ} \mathrm{C}, \mathrm{RT}$, or $37^{\circ} \mathrm{C}$ for 24 hours.

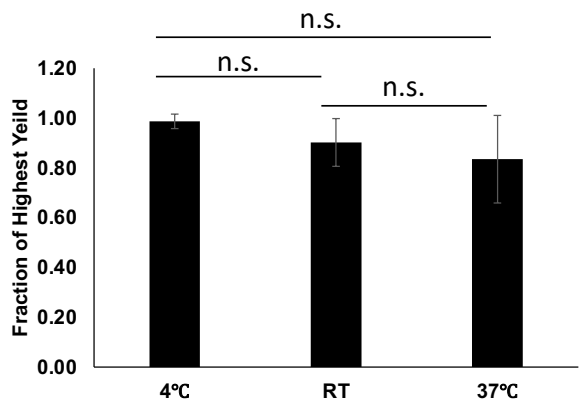

Figure 4: Temperature Stability. $\mathrm{N}=6$. Samples were mixed gently and split into 3 aliquots. Aliquots were stored at either $4^{\circ} \mathrm{C}$, RT, or $37^{\circ} \mathrm{C}$ for 24 hours. After 24 hours, RNA was extracted, and
Rer viral recovery was determined by qPCR. Error bars represent standard deviation. P-Values: $4^{\circ} \mathrm{C}$ to $\mathrm{RT}=0.097,4^{\circ} \mathrm{C}$ to $37^{\circ} \mathrm{C}=$ 0.108 , RT to $37^{\circ} \mathrm{C}=0.363$.

273 RNA was extracted from each sample, and SARS-CoV-2 signal was quantified using qPCR (Figure

274 4). Although samples that were maintained at $4^{\circ} \mathrm{C}$ had the least variability, there was no

275 significant difference in signal from samples kept at any temperature ( $P$ values range 0.097 to

276 0.363). This finding is interesting as an increase in temperature from $4^{\circ} \mathrm{C}$ to either $\mathrm{RT}$ or $37^{\circ} \mathrm{C}$

277 could impact the activity of various enzymes that could be present in raw wastewater and impact

278 rates of degradation of genetic material.

3.5 Detergent Removes SARS-CoV-2 Signal.

Because SARS-CoV-2 is an enveloped virus, it is very likely to be sensitive to detergent

281 because of a disruption of the lipids composing the envelope. Presence of an envelope may

protect genomic material from enzymes that may quickly

284 to whether the SARS-CoV-2 signal detected in

285 wastewater was sensitive to detergent. To answer this

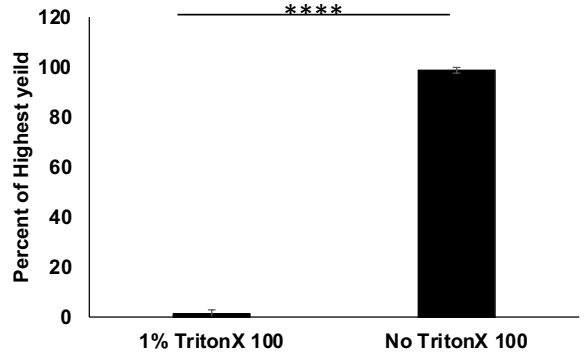

Figure 5: Detergent Sensitivity. $\mathrm{N}=6$. Duplicate samples were

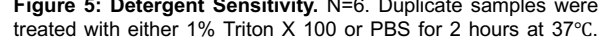
RNA was extracted from raw samples, and viral recovery was determined by qPCR. Error bars represent standard deviation. P-
Value $=2.10 \mathrm{E}-20$. 
medRxiv preprint doi: https://doi.org/10.1101/2021.07.19.21260777; this version posted July 25, 2021. The copyright holder for this preprint (which was not certified by peer review) is the author/funder, who has granted medRxiv a license to display the preprint in perpetuity.

It is made available under a CC-BY-NC-ND 4.0 International license . about 100-fold in comparison to samples treated with PBS alone. Contrary to our original hypothesis, this indicates that SARS-CoV-2 signal detected in wastewater is likely protected by a

291 lipid bilayer, but this finding could also have other causes.

\subsection{Density of SARS-CoV-2.}

294 including breaking up of protein complexes. Because of this, we wanted to know if the density of

299 was extracted from each

300 fraction (Figure 6). Each fraction

301 was then probed by qPCR for

302 SARS-CoV-2 signal and the Puro

303 Virus control. The fraction

304 containing the highest signal for

305 both the Puro Virus and SARS-

306 CoV-2 correlates with a density

$307(\rho)$ between 1.16 and $1.18 \mathrm{~g} \cdot \mathrm{mL}^{-}$

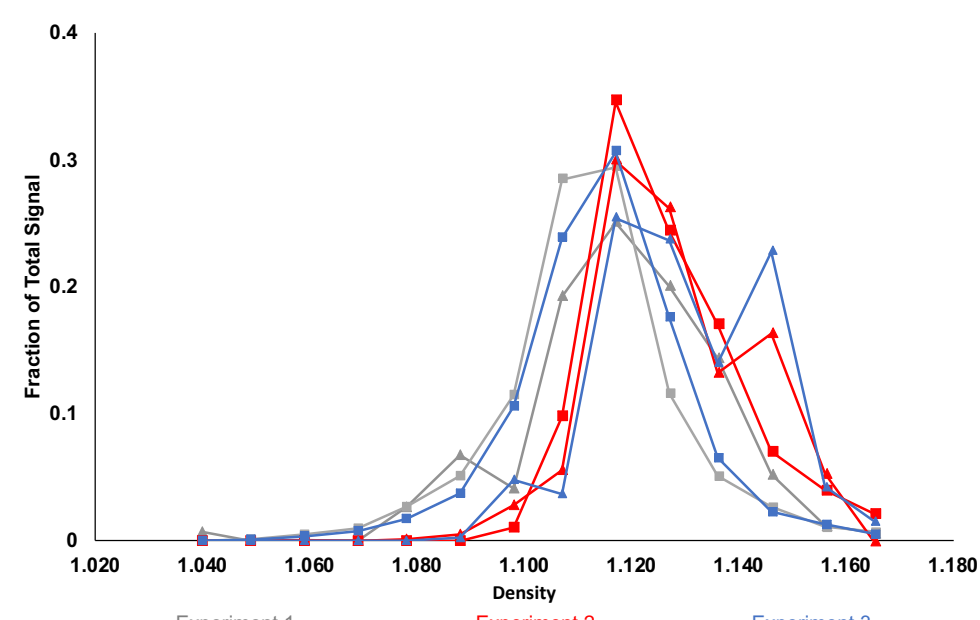

$\rightarrow$ SARS-CoV-2 $\rightarrow$ Puro Virus $\rightarrow$ SARS-CoV-2 $\rightarrow$-Puro Virus $\rightarrow$ SARS-CoV-2 $\rightarrow$-Puro Virus

Figure 6: Density. $\mathrm{N}=3$. Puro Virus was added to raw wastewater samples at a concentration of $4.8 \times 10^{7}$ viral particles per sample. Raw samples were concentrated then added to a density gradient ranging from $0 \%$ to $28 \%$ iodixanol in a $0.25 \mathrm{M}$ sucrose dilutant and spun in a Sorvall Discovery $100 \mathrm{SE}$ ultracentrifuge at 31,000 RPM for 3 hours at $4^{\circ}$ C. RNA was extracted from fractions, and viral recovery was determined by qPCR.

$308{ }^{1}$ as calculated according to the Optiprep protocol and confirmed by refractometer. This finding 
medRxiv preprint doi: https://doi.org/10.1101/2021.07.19.21260777; this version posted July 25, 2021. The copyright holder for this preprint (which was not certified by peer review) is the author/funder, who has granted medRxiv a license to display the preprint in perpetuity.

It is made available under a CC-BY-NC-ND 4.0 International license .

is in agreement with the expected density of retroviruses and further supports that the genetic

material wastewater is similar to an enveloped viral particle [36].

\subsection{No Cytopathic Effects from Wastewater Samples.}

The similarities in density along with detergent sensitivity suggest that the genetic

particles. To examine this question, aliquots of 10 raw wastewater samples from the week of

315 June $28^{\text {th }}, 2021$, with SARS-CoV-2 signals ranging from 169,433 to $3,255,921$ Copies/L were

the experiment (Figure 7). The absence of cytopathic effects suggests that wastewater samples
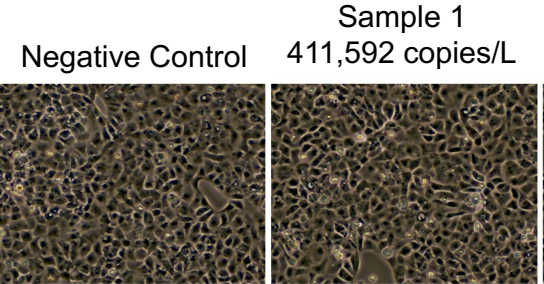

Positive Control

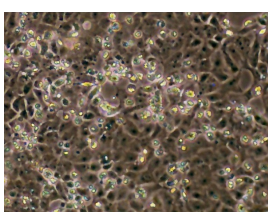

Sample 1 411,592 copies/L

Sample 6 169,433 copies/L

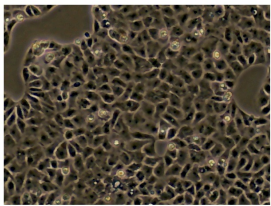
57,508 copies/L

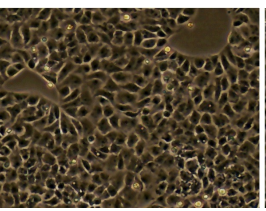

Sample 2

Sample 7

Sample 3 842,212 copies/L

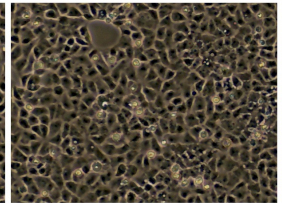

Sample 8 315,973 Copies/L 480,376 copies/L
Sample 4 502,970 copies/L

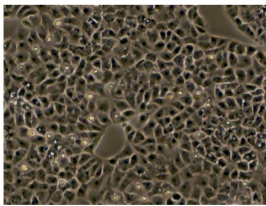

Sample 9 114,736 copies/L

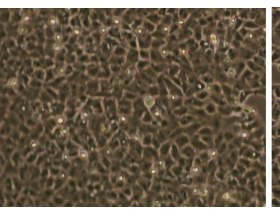

Sample 5 227,742 copies/L

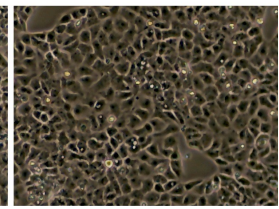

Sample 10 3,255,921 copies/L

Figure 7: Infectivity. CPE of Vero E6 cells 3 days post inoculation with fresh wastewater samples. Images taken 3 days after the $3^{\text {rd }}$ inoculation. Ten total samples were tested. Numbers above each picture represent the copy number per liter from that sample as measured by qPCR.

320 do not contain infectious SARS-CoV-2 Particles. As a positive control, cells were infected with

321 SARS-CoV-2/human/USA/20x1003/2020 (GenBank Accession ID: MW521470.1) at a MOI of

3220.001 . These cells showed significant cytopathic effects whereas the negative control cells had 
medRxiv preprint doi: https://doi.org/10.1101/2021.07.19.21260777; this version posted July 25, 2021. The copyright holder for this preprint (which was not certified by peer review) is the author/funder, who has granted medRxiv a license to display the preprint in perpetuity.

It is made available under a CC-BY-NC-ND 4.0 International license .

\section{DISCUSSION}

COVID-19 causes a wide variety of symptoms and disease severity. This combined with

327 inaccessibility to testing due partially to supply costs, availability, and varied access to healthcare

328 makes accurately tracking cases of COVID-19 difficult. Like several other viruses, SARS-CoV-2 was

329 shown to be present in the COVID-19 patient feces and therefore wastewater despite being

330 primarily transmitted via respiratory droplets [9-13]. To date, there have been no confirmed

331 cases of SARS-CoV-2 infection from wastewater treatment plants, and infectious virus has not

332 been able to be reliably cultured from wastewater [25-27]. In early stages of the pandemic and

333 during periods of lower community spread of SARS-CoV-2, it has been necessary to concentrate

334 wastewater samples to reliably detect genetic material using qPCR. Using samples from

335 communities with high community levels of COVID-19, we have shown that filtration and

336 concentration of wastewater samples reliably reserves $\sim 60 \%$ of signal from raw wastewater,

337 supporting that this method of filtering and concentration is a consistent method for

338 concentrating and comparing community viral loads (Figure 1). While the method described here

339 includes filtration through a $0.22 \mu \mathrm{m}$ filter to remove other debris and bacterial pathogens, other

340 groups have suggested pasteurizing wastewater samples to inactivate any pathogens present in

341 wastewater. We have shown here that pasteurizing samples for 2 hours does not impact signal if

342 RNA is extracted from samples immediately; however, this does not remain true for samples that

343 have been pasteurized and returned to $4{ }^{\circ} \mathrm{C}$ for RNA extraction between 24 - and 36-hours post-

344 pasteurization (Figure 2). While the decrease in signal is approximately 2-fold, it remains an 
medRxiv preprint doi: https://doi.org/10.1101/2021.07.19.21260777; this version posted July 25, 2021. The copyright holder for this preprint (which was not certified by peer review) is the author/funder, who has granted medRxiv a license to display the preprint in perpetuity.

It is made available under a CC-BY-NC-ND 4.0 International license .

345 important note that pasteurization may make a consistent experimental timeline of higher

346 importance for those who are quantifying viral loads after pasteurization.

Interestingly, we noticed that recovery of the Puro Virus control was consistently about

348 3-fold lower than the recovery of SARS-CoV-2 through concentration (Figure 3B). Initially, this led

349 us to believe that the SARS-CoV-2 signal present in wastewater was coming from a different

350 source than an enveloped particle, but our data suggests the contrary and led us to investigate

351 the nature of the genomic material producing signal.

352

From the time it is deposited into a sewer system to its arrival at a wastewater treatment

353 plant, a fecal sample may go through a variety of temperature changes. Additionally, as

354 temperatures get closer to $37^{\circ} \mathrm{C}$, enzymes that degrade genetic material may become more

355 active. We show that in a 24-hour period, temperature changes are tolerated as there is no

356 significant difference in signals from samples kept at $4^{\circ} \mathrm{C}$, room temperature, or $37^{\circ} \mathrm{C}$ (Figure 4).

357 This finding is interesting as it suggests some sort of protection of genetic material from

358 degradation and suggests that outdoor temperatures may not impact reliability of signal

359 detection when levels of SARS-CoV-2 genetic material are monitored over time.

360 Because of high levels of genomic material found in feces, it was a high concern early in

361 the pandemic that feces and wastewater may be a source infectious virus; however, many efforts

362 to culture infectious virus from fecal or wastewater samples have failed [21-23]. Here we

363 demonstrate that genomic RNA collected from wastewater samples is sensitive to detergent

364 which suggests that the genomic material is protected by a lipid bilayer (Figure 5). Additionally,

365 the material concentrated from wastewater samples has a very similar density to non-infectious

366 retroviral particles again supporting that the material concentrated from wastewater shares 
medRxiv preprint doi: https://doi.org/10.1101/2021.07.19.21260777; this version posted July 25, 2021. The copyright holder for this preprint (which was not certified by peer review) is the author/funder, who has granted medRxiv a license to display the preprint in perpetuity.

It is made available under a CC-BY-NC-ND 4.0 International license .

367 similarities to an enveloped viral particle (Figure 6). In agreement with prior findings discussed

368 above, wastewater samples did not contain any infectious SARS-CoV-2 particles (Figure 7). It is

369 feasible that enzymes present in the digestive tract, such as Trypsin, cleave much of the Spike

370 glycoprotein from virus present in the digestive tract resulting in viral particles that are enveloped

371 yet not infectious. Further studies need to be done to determine whether the genomic material

372 is full length SARS-CoV-2 genomic material and to investigate why the genomic material found in

373 wastewater may be non-infectious while also remaining to be protected by a lipid bilayer.

374

\section{FUNDING ACKNOWLEGEMENT}

376 Funding for the project was administered by the Missouri Department of Health and Senior

377 Services (DHSS). This project was supported by funding from the Centers for Disease control and

378 the National Institutes of Health grant U01DA053893-01

379 
medRxiv preprint doi: https://doi.org/10.1101/2021.07.19.21260777; this version posted July 25, 2021. The copyright holder for this preprint

(which was not certified by peer review) is the author/funder, who has granted medRxiv a license to display the preprint in perpetuity. It is made available under a CC-BY-NC-ND 4.0 International license .

\section{References:}

382

383

384

385

386

387

388

389

390

391

392

393

394

395

396

397

398

399

400

401

402

403

404

405

406

407

408

409

410

411

412

413

414

415

416

417

418

419

420

421

1. Wang, J. and G. Du, COVID-19 may transmit through aerosol. Ir J Med Sci, 2020. 189(4): p. 1143-1144.

2. Zhu, N., et al., A Novel Coronavirus from Patients with Pneumonia in China, 2019. N Engl J Med, 2020. 382(8): p. 727-733.

3. Zhong, N.S., et al., Epidemiology and cause of severe acute respiratory syndrome (SARS) in Guangdong, People's Republic of China, in February, 2003. Lancet, 2003. 362(9393): p. 1353-8.

4. Ksiazek, T.G., et al., A novel coronavirus associated with severe acute respiratory syndrome. N Engl J Med, 2003. 348(20): p. 1953-66.

5. Drosten, C., et al., Identification of a novel coronavirus in patients with severe acute respiratory syndrome. N Engl J Med, 2003. 348(20): p. 1967-76.

6. Yan, R., et al., Structural basis for the recognition of SARS-CoV-2 by full-length human ACE2. Science, 2020. 367(6485): p. 1444-1448.

7. Hamming, I., et al., Tissue distribution of ACE2 protein, the functional receptor for SARS coronavirus. A first step in understanding SARS pathogenesis. J Pathol, 2004. 203(2): p. 631-7.

8. $\mathrm{Xu}, \mathrm{H}$., et al., High expression of ACE2 receptor of 2019-nCoV on the epithelial cells of oral mucosa. Int J Oral Sci, 2020. 12(1): p. 8.

9. Corman, V.M., et al., Viral Shedding and Antibody Response in 37 Patients With Middle East Respiratory Syndrome Coronavirus Infection. Clin Infect Dis, 2016. 62(4): p. 477-483.

10. Leung, W.K., et al., Enteric involvement of severe acute respiratory syndrome-associated coronavirus infection. Gastroenterology, 2003. 125(4): p. 1011-7.

11. Gu, J., B. Han, and J. Wang, COVID-19: Gastrointestinal Manifestations and Potential Fecal-Oral Transmission. Gastroenterology, 2020. 158(6): p. 1518-1519.

12. Holshue, M.L., et al., First Case of 2019 Novel Coronavirus in the United States. N Engl J Med, 2020. 382(10): p. 929-936.

13. Song, Y., et al., SARS-CoV-2 induced diarrhoea as onset symptom in patient with COVID19. Gut, 2020. 69(6): p. 1143-1144.

14. Chen, Y., et al., The presence of SARS-CoV-2 RNA in the feces of COVID-19 patients. J Med Virol, 2020. 92(7): p. 833-840.

15. Katayama, H., et al., One-year monthly quantitative survey of noroviruses, enteroviruses, and adenoviruses in wastewater collected from six plants in Japan. Water Res, 2008. 42(67): p. 1441-8.

16. Fumian, T.M., et al., Detection of rotavirus $A$ in sewage samples using multiplex $q P C R$ and an evaluation of the ultracentrifugation and adsorption-elution methods for virus concentration. J Virol Methods, 2010. 170(1-2): p. 42-6.

17. Wang, X.W., et al., Excretion and detection of SARS coronavirus and its nucleic acid from digestive system. World J Gastroenterol, 2005. 11(28): p. 4390-5.

18. Kroiss, S.J., et al., Assessing the sensitivity of the polio environmental surveillance system. PLoS One, 2018. 13(12): p. e0208336. 
medRxiv preprint doi: https://doi.org/10.1101/2021.07.19.21260777; this version posted July 25, 2021. The copyright holder for this preprint

(which was not certified by peer review) is the author/funder, who has granted medRxiv a license to display the preprint in perpetuity. It is made available under a CC-BY-NC-ND 4.0 International license .

422 19. Peccia, J., et al., Measurement of SARS-CoV-2 RNA in wastewater tracks community

423

424

425

426

427

428

429

430

431

432

433

434

435

436

437

438

439

440

441

442

443

444

445

446

447

448

449

450

451

452

453

454

455

456

457

458

459

460

461 infection dynamics. Nat Biotechnol, 2020. 38(10): p. 1164-1167.

20. Asghar, H., et al., Environmental surveillance for polioviruses in the Global Polio Eradication Initiative. J Infect Dis, 2014. 210 Suppl 1: p. S294-303.

21. Wolfel, R., et al., Author Correction: Virological assessment of hospitalized patients with COVID-2019. Nature, 2020. 588(7839): p. E35.

22. Chen, Y., et al., Structure analysis of the receptor binding of 2019-nCoV. Biochem Biophys Res Commun, 2020.

23. Ling, Y., et al., Persistence and clearance of viral RNA in 2019 novel coronavirus disease rehabilitation patients. Chin Med J (Engl), 2020. 133(9): p. 1039-1043.

24. Xiao, F., et al., Evidence for Gastrointestinal Infection of SARS-CoV-2. Gastroenterology, 2020. 158(6): p. 1831-1833 e3.

25. Gundy, P.M., C.P. Gerba, and I.L. Pepper, Survival of Coronaviruses in Water and Wastewater. Food and Environmental Virology, 2009. 1(1): p. 10.

26. Wang, X.W., et al., Study on the resistance of severe acute respiratory syndromeassociated coronavirus. J Virol Methods, 2005. 126(1-2): p. 171-7.

27. Ye, Y., et al., Survivability, Partitioning, and Recovery of Enveloped Viruses in Untreated Municipal Wastewater. Environ Sci Technol, 2016. 50(10): p. 5077-85.

28. Ahmed, W., et al., Comparison of virus concentration methods for the RT-qPCR-based recovery of murine hepatitis virus, a surrogate for SARS-CoV-2 from untreated wastewater. Sci Total Environ, 2020. 739: p. 139960.

29. Corpuz, M.V.A., et al., Viruses in wastewater: occurrence, abundance and detection methods. Sci Total Environ, 2020. 745: p. 140910.

30. Philo, S.E., et al., A comparison of SARS-CoV-2 wastewater concentration methods for environmental surveillance. Sci Total Environ, 2021. 760: p. 144215.

31. Kanarek, A.D. and G.W. Tribe, Concentration of certain myxoviruses with polyethylene glycol. Nature, 1967. 214(5091): p. 927-8.

32. Vajda, B.P., Concentration and purification of viruses and bacteriophages with polyethylene glycol. Folia Microbiol (Praha), 1978. 23(1): p. 88-96.

33. Kohno, T., et al., A new improved method for the concentration of HIV-1 infective particles. J Virol Methods, 2002. 106(2): p. 167-73.

34. Zufferey, R., et al., Multiply attenuated lentiviral vector achieves efficient gene delivery in vivo. Nature Biotechnology, 1997. 15(9): p. 871-5.

35. Pecson, B.M., et al., Reproducibility and sensitivity of 36 methods to quantify the SARSCoV-2 genetic signal in raw wastewater: findings from an interlaboratory methods evaluation in the U.S. Environ Sci (Camb), 2021. 7: p. 504-520.

36. Poiesz, B.J., et al., Detection and isolation of type C retrovirus particles from fresh and cultured lymphocytes of a patient with cutaneous T-cell lymphoma. Proc Natl Acad Sci U S A, 1980. 77(12): p. 7415-9. 